\title{
Avoiding Us versus Them: How Schools' Dependence on Privileged "Helicopter" Parents Influences Enforcement of Rules
}

\author{
Jessica McCrory Calarco \\ Indiana University
}

Corresponding Author: Jessica McCrory Calarco

Address: 1020 E Kirkwood Ave, \#744, Bloomington, IN 47405-7103

Email: jcalarco@indiana.edu

*this manuscript has been accepted for publication in the American Sociological Review and will appear in the April 2020 issue*

\begin{abstract}
As privilege-dependent organizations, U.S. public schools have an interest in catering to higher-SES White families. But, what happens when privileged families' interests conflict with schools' stated goals? Focusing on the case of homework, and drawing insights from organizational theory, cultural capital theory, and research on parent involvement in schools, I examine how schools' dependence on higherSES White families influences their enforcement of rules. Using a longitudinal, ethnographic study of one socioeconomically diverse public elementary school, I find that teachers wanted to enforce homework rules, but they worried doing so would lead to conflict with the higher-SES White "helicopter" parents, on whom they relied most for support. Thus, teachers selectively enforced rules, using evidence of "helicopter" parenting to determine which students "deserved" leeway and lenience. Those decisions, in turn, contributed to inequalities in teachers' punishment and evaluation of students. Broadly, these findings suggest privilege-dependence leads schools to appease privileged families, even when those actions contradict the school's stated goals. These findings also challenge standard policy assumptions about parent involvement and homework, and they suggest policies aimed at reducing the power of privilege are necessary for lessening inequalities in school.
\end{abstract}

\section{Keywords}

Organizations, Inequality, Schools, Families, Rules 
Schools are privilege-dependent organizations, deriving social and economic status from that of the families they serve (Condron and Roscigno 2003; Hasan and Kumar 2019; Lareau and Goyette 2014; Logan et al. 2018; Murray et al. 2019; Zimmer and Jones 2005). Privilege-dependence gives schools an interest in catering to higher-SES (i.e., affluent and well-educated) White families (Cucchiara 2013; Hamilton 2016; Khan 2012; Lewis and Diamond 2015; Lewis-McCoy 2014; Posey-Maddox 2014; Tilly 1999). But, what happens when privileged families' interests conflict with schools' stated goals? We know that higher-SES White families are willing to challenge school rules, policies, and procedures (Calarco 2018; Horvat, Weininger, and Lareau 2003; Lareau 2000; Lareau, Weininger, and Cox 2018; Lewis and Diamond 2015; Lewis-McCoy 2014). Less clear, however, is how schools' dependence on privileged families influences rule enforcement. What factors do schools consider in deciding when to enforce rules? Who do those decisions benefit? How do schools justify those benefits? How do those benefits reduce or reinforce inequalities?

To answer these questions, I focused on the case of homework rules, drawing data from a longitudinal, ethnographic study of teachers, students, and parents at Maplewood Elementary School.1 I found that Maplewood was economically and socially dependent on higher-SES White families and especially families with highly-involved "helicopter" parents. That dependence led teachers to appease these parents, even when doing so contradicted stated goals. That appeasement was particularly consequential in teachers' enforcement of homework rules. Teachers wanted to enforce the rules, but they worried doing so would lead to conflict with privileged parents. Thus, teachers selectively enforced rules, using evidence of "helicopter" parenting to determine which students most "deserved" leeway with rules. Because lower-SES White parents rarely had the resources for "helicopter"-like involvement, teachers rarely perceived lower-SES White children as worthy of exemptions from rules. Although teachers did not intend to treat students unfairly, their unequal rule enforcement ultimately reinforced inequalities in the punishment and evaluation of students.

These findings suggest that schools are heavily dependent on privileged families and such privilegedependence has tangible consequences for schools' enforcement of rules. Building on insights from organizational theory (Martin et al. 2013; Meyer and Rowan 1977; Tilly 1999; Weick 1976), cultural capital theory (Bourdieu and Passeron 1990; Lamont and Lareau 1988; Lareau and Weininger 2003), and research on within-SES variations in parent involvement in schooling (Haley-Lock and Posey-Maddox 2016; Hamilton 2016), these findings reveal how teachers decided to grant exemptions from rules and how they justified doing so in unequal ways.

Ultimately, and despite their criticisms of privileged "helicopter" parents, teachers could still be compelled - by the power of privilege-dependence - to grant those parents and their children the leeway with rules they desired. In documenting the consequences of these organizational processes for teachers' treatment and evaluation of students, this study heeds the call for research on how organizations reproduce inequalities (Abrutyn and Turner 2011; King 2017; Martin et al. 2013; Ray 2019; TomaskovicDevey and Avent-Holt 2016), challenges commonly-held assumptions about parent involvement and homework, and suggests that policies to reduce the power of privilege are necessary for lessening inequalities in school. 


\title{
BACKGROUND AND JUSTIFICATION
}

\author{
Schools' Dependence on Privilege
}

Many organizations exhibit privilege-dependence, 2 but U.S. public schools are a particularly strategic case, as their social and economic status is closely linked to the social and economic status of the communities they serve. Economically, U.S. public schools often receive a substantial portion of their funding from local sources such as property taxes and school bonds (Condron and Roscigno 2003; Leachman, Masterson, and Figueroa 2017; Zimmer and Jones 2005). As a result, schools in higher-SES White communities typically have more resources than schools in lower-SES communities and communities of color (Condron and Roscigno 2003; Epstein 2011; Logan, Minca, and Adar 2012; Wenglinsky 1997).3 Even where funding is more centralized, higher-SES White families use individual donations and Parent-Teacher Organization (PTO) fundraisers to provide supplemental funding for their children's schools (Cucchiara 2013; Murray et al. 2019; Posey-Maddox 2014).

Socially, the perceived quality and desirability of U.S. public schools is closely linked to the status of families they serve. Families consider many factors in choosing schools for their children, and some schools are seen as "higher quality" than others (Lareau and Goyette 2014). Perceptions of "quality" are often closely linked to schools' socioeconomic and racial composition (Bourdieu 1984; Krysan, Crowder, and Bader 2014; Sikkink and Emerson 2008; Weininger 2014), and they reflect the fact that schools with larger proportions of higher-SES White students typically have higher standardized test scores and more amenities (e.g., smaller class sizes, more experienced teachers, more course offerings, more technology) than do other schools (Condron and Roscigno 2003; Duke 2000; Klugman 2013; Logan et al. 2012; Rafalow 2018; Shedd 2015; Wenglinsky 1997). Because of the perceived benefits, families (especially higher-SES White families) are willing to pay more to live in neighborhoods with "high-quality" schools (Barrow 2002; Hasan and Kumar 2019). High housing prices drive out lower-SES families (Pattillo, Delale-O'Connor, and Butts 2014; Rhodes and DeLuca 2014) while increasing the funding base for local public schools (Epstein 2011; Leachman et al. 2017).

Given their privilege-dependence, we know that U.S. public schools have an interest in catering to higherSES, White families (Cucchiara 2013; Hamilton 2016; Khan 2012; Lewis-McCoy 2014; Tilly 1999). Privileged families, however, do not always have the same interests as schools. Rather, higher-SES White families sometimes challenge school rules, policies, and procedures (Cucchiara 2013; Horvat et al. 2003; Lareau and Horvat 1999; Lareau et al. 2018; Lewis-McCoy 2014; Posey-Maddox 2014; Posey-Maddox, Kimelberg, and Cucchiara 2016). Higher-SES White families use those challenges to try to "hoard opportunities" (Tilly 1999), and they are often successful in doing so.

Privilege-Dependence and Rule Enforcement 
Less clear, however, is how privilege-dependence influences schools' enforcement of rules. Do schools always allow privileged families to break rules without consequence? If not, what factors do schools consider in deciding when to enforce the rules? Which families benefit most from those decisions? How do schools justify those benefits? And, how do those benefits reduce or reinforce the inequalities that make schools dependent on the privileged people they serve?

Existing research has not specifically answered those questions, but it does point to three key propositions. First, organizational theory suggests schools might opt not to enforce rules when doing so would create conflict with the families on whom they depend. When organizations grant rule exemptions, they effectively sanction rule-breaking (Martin et al. 2013). Thus, rule exemptions lead to a form of "loose coupling," where organizational practices are inconsistent with official rules (Meyer and Rowan 1977; Weick 1976). According to neoinstitutional theory, organizations use loose coupling to avoid conflicts that might jeopardize their legitimacy in the eyes of external audiences and authorities. Neoinstitutional theory says little about inequality in organizations, 4 but other scholars find evidence that socioeconomic and racial diversity can be a source of conflict in organizations (Braunstein, Fulton, and Wood 2014; Kadushin et al. 2005; Leondar-Wright 2005). Organizations, in turn, might use rule exemptions to manage conflicts and appease the privileged constituents on whom they most depend. That would align with Tilly's (1999:10) model of “durable inequality," in which people and organizations "rarely set out to manufacture inequality" but rather do so as a byproduct of their efforts to "solve other organizational problems."

Second, research on within-SES variations in parent involvement suggests schools will be most dependent on (and thus most interested in catering to) higher-SES White families with highly-involved "helicopter" parents. Higher-SES White parents vary in their level of school involvement (Haley-Lock and Posey-Maddox 2016; Hamilton 2016; Muller 1995). Haley-Lock and Posey-Maddox (2016), for example, reveal how mothers' employment shapes the level of support they can provide. Hamilton (2016) distinguishes "helicopter" parents (who are constantly hovering, ready to swoop in and solve problems) from "paramedics" (who provide occasional, strategic support and involvement) and "bystanders" (who provide some support, especially at home, but rarely intervene). Hamilton explains how, in an era of tight budgets and competition for the "best" students, universities are especially dependent on "helicopter" parents for their consistent social and economic support. Hamilton's research does not examine how schools manage their dependence on "helicopter" parents, but other research shows schools (including primary and secondary schools) are extremely responsive to the demands of highly-involved parents (Cucchiara 2013; Horvat et al. 2003; Lareau and Horvat 1999; Lareau et al. 2018; Lewis and Diamond 2015; Lewis-McCoy 2014; Posey-Maddox 2014; Posey-Maddox et al. 2016).

Third, cultural capital theory suggests schools might use privileged families' general compliance with expectations to justify rewarding those families with occasional exemptions from rules. As cultural capital theory suggests, organizations establish expectations and reward people who comply with those expectations (Bourdieu and Passeron 1990; Lamont and Lareau 1988; Lareau and Weininger 2003). Because dominant institutions are controlled by privileged people, expectations in those settings typically favor privileged groups (Bourdieu 1984; Bourdieu and Passeron 1990; Lamont and Lareau 1988; Lareau and Weininger 2003). As a result, privileged people have the resources to follow organizational rules, and organizations reward them for their compliance. That compliance, in turn, might allow organizations to 
justify offering privileged people at least occasional exemptions from the rules. If that is the case, then it could help explain why the people who are best able to follow organizational rules (i.e., higher-SES White people) are also most successful in challenging rules and breaking them without consequence (Gage-Bouchard 2017; Gengler 2014; Jacques and Wright 2015; Khan 2012; Lewis and Diamond 2015; Lewis-McCoy 2014; Morris 2005).

\section{The Case of Homework}

I consider the three propositions outlined above using the case of elementary schools and their enforcement of homework rules. Elementary schools are a particularly rule-governed environment, and many of those rules have to do with homework (Jackson, Boostrom, and Hansen 1993). Before the 1950s, homework involved basic memorization and was typically given only in small amounts to older children (Gill and Schlossman 2004). Over time, however, concerns about international competitiveness prompted schools to assign more homework, more rigorous homework, and homework in earlier grades (Gill and Schlossman 2003). Currently, teachers use homework to reinforce material learned at school (Cooper, Robinson, and Patall 2006; Vatterott 2011) and to develop "soft" skills like work-ethic and responsibility (Bempechat 2004; Farkas et al. 1990).

Evidence also suggests, however, that higher-SES White students (especially those with "helicopter" parents) have advantages in both completing homework and avoiding homework-related punishments (Daw 2012; Rønning 2011; Xu 2011).5 Many higher-SES White parents (especially mothers) provide high levels of support with homework (Baker and Stevenson 1986; Epstein 1988; Forsberg 2007; HooverDempsey et al. 2001; Lau, Li, and Rao 2011; Patall, Cooper, and Robinson 2008; Robinson and Harris 2014; Schieman, Ruppanner, and Milkie 2018). Such support is beneficial for students (Li and Hamlin 2019; Patall et al. 2008) because problems with homework can lead to negative evaluations (Farkas et al. 1990; McMillan, Myran, and Workman 2002) and disciplinary sanctions (Golann 2015). Beyond just providing support with homework, however, there is reason to suspect that higher-SES White "helicopter" parents will also intervene to prevent or manage problems with homework (Lareau 2000; Milkie and Warner 2014; Nelson 2010). These parents, might, for example, demand their children be excused from homework or homework-related punishments, or they might do children's homework for them to ensure it gets done correctly and on-time. Such homework-related interventions could further explain higher-SES White students' homework-related advantages in school.

\section{DATA AND METHODS}

Building on these findings, I consider how schools' dependence on higher-SES White "helicopter" parents shapes their enforcement of homework rules. I base these analyses on a longitudinal, ethnographic study of teachers, administrators, parents, and students in a suburban, public elementary school (for more information, see Calarco 2018). In doing so, I treat schools not as abstract agents but rather as "inhabited" institutions, constituted by the people and interactions within them (Hallett and Ventresca 2006). 


\section{Research Site and Permissions}

Maplewood is a high-achieving, public elementary school outside a large, Eastern city. The single-story, brick building is clean, bright, and colorful. Parents (especially higher-SES White mothers) are often buzzing about, helping with volunteer projects or chatting with teachers and staff.

During my observations, Maplewood had approximately 500 students, with four classrooms in each grade. Maplewood's students were primarily higher-SES (75 percent), as defined by parents' educational and occupational status (Lareau 2011).6 The school was primarily White and non-Hispanic/Latinx (82 percent), 7 but it also had Latinx students (9 percent, mostly lower-SES), Asian American students (6 percent, mostly higher-SES), and Black and mixed-race students (3 percent, mixed class backgrounds).

I selected Maplewood because its demographics allowed me to observe students from different SES backgrounds in the same classrooms. The ideal school for that purpose would include more families of color and would represent the full range of intersections between race, ethnicity, and social class. Unfortunately, because of high levels of segregation in U.S. public schools (Reardon and Owens 2014), it is difficult to find schools matching that profile. Some public schools are more racially and ethnically diverse; however, race, ethnicity, and social class tend to be closely linked in those settings, which affects the relationships between families and schools (Cucchiara 2013; Hagerman 2018; Lewis and Diamond 2015; Posey-Maddox 2014). I focus here on social class-based inequalities among White, nonHispanic/Latinx students, and future research should investigate these patterns in other settings.

Before beginning data collection, I met with district officials to discuss the project and obtain permission to conduct this research. I then sought and received IRB approval before enrolling participants. The participants included families with children in 3rd grade at Maplewood at the start of the project, as well as the teachers and administrators who worked with those students.

\section{Data Collection}

Like many ethnographic studies, this project incorporated data from multiple sources, including in-depth interviews, observations, surveys, and administrative records. The interview sample includes 14 teachers and administrators, 24 parents, and 21 children. Table 1 includes background characteristics for student and parent interview participants, all of whom were White and non-Hispanic/Latinx.

\section{[TABLE 1 ABOUT HERE]}

My observations at Maplewood followed a cohort of students from 3rd through 5th grade. Those observations, which took place from March 2008 to June 2010, included 17 teachers (regular classroom 
teachers and enrichment teachers), more than 100 students, and dozens of parents who visited the school to volunteer or attend special events. The cohort experienced some turnover from year to year, with new students entering and some students leaving the school.

During the observation phase, I visited Maplewood at least twice weekly, for about three hours per visit. I divided those observations across the four classrooms in each grade, and I also observed during lunch, recess, and other school events. I occasionally helped teachers with classroom tasks, but I spent most of my time watching and taking notes. My in-the-field jottings included snippets of dialog along with brief notes on interactions I observed. After leaving the field, I expanded those jottings into detailed fieldnotes revealing the meaning and context of those interactions (Emerson, Fretz, and Shaw 2011; Hammersley and Atkinson 2007). That process typically took three to four hours for every hour of fieldwork.

In addition to observations, I also conducted interviews with all the 3rd-, 4th-, and 5th-grade teachers at Maplewood and with a sample of the students and parents I observed. Teachers were interviewed during the observation phase at Maplewood. Parents and students were interviewed after the completion of the observations at Maplewood (summer 2010, with follow-up interviews during summer 2012). Interviews lasted, on average, 90 minutes and were audio-recorded and transcribed. In arranging parent interviews, I asked to speak with the focal child's primary caregiver. Usually, and consistent with research on gender and parenting (Dow 2019; Hays 1998; Lareau 2011; Schieman et al. 2018; Villalobos 2014), that meant mothers. In two cases, I interviewed single fathers (both lower-SES). In three cases (all higher-SES), I interviewed a student's mother and father together. After completing the parent interview, I asked to interview the focal child. I also supplemented formal interviews with informal conversations, which I documented in fieldnotes.

For the purpose of triangulation, I also collected data from parent surveys and school records. Background surveys were completed by 80 families, and I used these to determine students' social class, race, and ethnicity. 8 Table 1 breaks down the survey sample by students' social class, race, and ethnicity.

I also gathered data from relevant administrative records. The bulk of those data are from students' school records, including grades and teacher evaluations of student behavior. The school stored the records in paper files for each student, and it took me nearly 80 hours to digitize the data. 9 The school record data exclude students who were initially part of the project but moved away before the end of 5th grade. They also exclude students whose parents did not provide permission for access to school records. Table 1 includes information about the school record sample.

In addition to school records, I used a variety of online record sources to gather information relevant to understanding Maplewood's dependence on the privileged families it served. Those sources included school board documents (e.g., budgets, meeting minutes, teacher salary data schedules), local newspaper reports, property assessment records, PTO budget documents, state department of education records, and online school ratings. 


\section{Data Analysis}

Throughout the project, I wrote analytic memos (Hammersley and Atkinson 2007; Lareau 2000) describing emerging themes like "rule exemptions," "rule enforcement," and "parent involvement." I then used ATLAS.ti to code parts of fieldnotes and interviews that aligned with the themes. While coding, I also created data matrices (Miles, Huberman, and Saldaña 2013) to clarify patterns and identify disconfirming evidence.

Using these data, I examined how Maplewood depended on higher-SES White families and how that dependence affected Maplewood's enforcement of rules. Specifically, I examined the factors teachers considered in granting rule exemptions, how those factors favored higher-SES White students with "helicopter" parents, and how those processes reinforced inequalities. In doing so, I observed similar dynamics around rules about homework, attendance, teacher assignments, course placements, and even classroom snacks. In the interest of brevity, and because I observed decisions about homework rule enforcement during most field visits, I focus on the case of homework.

\section{MAPLEWOOD'S DEPENDENCE ON PARENTAL PRIVILEGE}

Like many other U.S. public schools, Maplewood was highly dependent on higher-SES White families. Economically, higher-SES, White families provided the bulk of Maplewood's official funding. During the years I observed, over 80 percent of Maplewood's funding came from local sources, including property taxes and school bonds.10 Although Maplewood's catchment area included two mobile home neighborhoods and a few lower-cost apartment complexes and townhome communities, the average home price in the community was more than $\$ 400,000$, and some homes were valued at $\$ 2$ million or more. The money generated from property taxes allowed Maplewood to provide a high level of support for teachers and students, including low class sizes (20 to 25 students), fair compensation for teachers (with a starting salary higher than $\$ 45,000$ and some teachers earning over $\$ 100,000$ a year), 11 and a wide array of enrichment classes (e.g., art, music, gym, library, Spanish), support programs (e.g., "gifted," learning support, guidance), and extracurricular activities (e.g., sports, clubs, art/music lessons). Shortly before I began my fieldwork, Maplewood also underwent multi-million-dollar renovations, funded through school bonds.

Economically, higher-SES White families (especially those with highly-involved "helicopter" parents) also offered supplemental support beyond what they paid in taxes. During the years I observed, the Parent Teacher Organization (PTO), which was run almost exclusively by higher-SES, White, stay-at-home or part-time-employed mothers, raised nearly $\$ 50,000$ a year (more than $\$ 100$ per student). Maplewood used PTO money for classroom technology like Smart Boards and laptops for every teacher; classroom materials such as art supplies, musical instruments, and science equipment; as well as playground toys, teacher and staff appreciation gifts, field trips, and special events featuring authors, artists, musicians, and scientists. 
In addition to financial support, higher-SES, White "helicopter" parents also offered critical logistical support to the school. Parent volunteers (most of whom were higher-SES White mothers) chaperoned field trips, ran after-school programs, helped with small-group reading instruction, and planned special events. That kind of parent volunteer support was particularly critical amidst what the school board called a "budget crisis." During my fieldwork, Maplewood was struggling to cover the rising costs of teacher salaries, benefits, and pensions; some community members were also pressuring the school board to lower property taxes. Faced with the possibility of sharp budget cuts, Maplewood relied heavily on higher-SES, White parents for donations and volunteer support. PTO parents and their children even testified at local school board meetings about the importance of investing in "high-quality" education.

Socially, higher-SES, White families also supported Maplewood's image as a "high-quality" school. During my fieldwork, Maplewood was rated 9/10 on GreatSchools.org, a website many families use when choosing schools (Hasan and Kumar 2019; Weininger 2014). Those ratings reflected students' standardized test scores, which were substantially higher than state averages, although not as high as in more affluent communities nearby. The high ratings were driven by test scores of the higher-SES White, non-Hispanic/Latinx and Asian American students at Maplewood, whose scores were much higher than those of their lower-SES Latinx and White, non-Hispanic/Latinx peers.12

\section{PRIVILEGE-DEPENDENCE AND THE PRESSURE TO APPEASE}

Because of their dependence on higher-SES, White families, Maplewood had an interest in appeasing those families and especially those who were highly involved at school. In the wake of the school's "budget crisis," for example, teachers talked explicitly about the need to avoid conflict with families. As 3rd-grade teacher Ms. Patterson explained:

One of the things you might want to think about is how a teacher feels their career is viewed from the parents and from the public. It's mixed, and lately it's been difficult with [teacher] salaries being posted in newspapers. I think overall the majority [of parents and community members] are grateful and supportive. But you have some out there that become so political that it [becomes] a strain. So, if we can avoid us versus them, that's a positive.

In the wake of the "budget crisis," teachers were also concerned about the possibility of higher-SES families leaving Maplewood for local private schools. They told me the loss of those families (what one teacher called "our best students") might hurt the school's reputation by lowering test scores and reducing donations and volunteers. Relatedly, during an informal conversation with 3rd-grade teacher Ms.

Patterson, she told me how she and the other teachers had to "keep the volunteers happy," noting that the school almost had to cancel a recent field trip because not enough parents initially offered to help. 
That pressure to appease higher-SES White "helicopter" parents led teachers to do what those parents wanted, even when it made more work for them. As 3rd-grade teacher Ms. Filipelli explained:

At Maplewood, I get lots of emails. Daily emails. A lot of emails. There's been one parent [a higher-SES, White mother], she's . . . oh my goodness. It's like I need a secretary to be dealing with all these emails. But I know those parents love their children. And those are the parents that help. So, if they have questions, I'm going to answer them. And you might find someone else complaining about it, but at [the lower-SES school where I used to teach], I never had any support. I would have, like, one parent helping. So, bring it on! I'm just happy to have the support.

Like Ms. Filipelli, teachers at Maplewood tried to appease the higher-SES White "helicopter" parents on whom they relied most for support. Teachers appeased those parents even when it made more work for them and, as I will show with homework, even when it went against what they believed was ultimately best for students.

\section{PRIVILEGE-APPEASEMENT AND EXEMPTIONS FROM RULES}

\section{Homework Rules}

The teachers and administrators at Maplewood believed in the importance of homework. The school handbook stated homework was intended to "promote independence" by helping students develop skills for "time management, responsibility, organization, and self-advocacy." Teachers echoed similar sentiments. As 5h-grade teacher Mr. Fischer explained:

I think homework should be a manageable practice of the day, plus some project work and some practice for tests that's metered out over time. And [students] should be able to do those things themselves. I tell them: "be a problem-solver instead of an excusemaker."

Ms. Campbell, a 3rd-grade teacher, also stressed the importance of responsibility with homework:

[Not meeting expectations] looks like not being prepared. Not having the homework. Not having a pencil. Like: "You're coming to this class, why would you not have those things? What are your priorities? What are your responsibilities as a 3rd grader?" 
Like Mr. Fischer and Ms. Campbell, teachers at Maplewood saw homework as an important tool for developing students' independence and responsibility.

Based on those views, teachers - at least officially — expected students to complete homework without much parent support. According to the school handbook, students in 3rd, 4th, and 5th grade would be expected to write down homework assignments, bring homework home, complete homework correctly, and bring homework back to school on time - all with little or no parent involvement. To further encourage students' independence with homework, Maplewood had a policy stating that parents would not be allowed to return to school to pick up or drop off children's forgotten assignments. The 3rd-, 4th-, and 5th-grade teachers also had classroom homework policies with penalties for late, forgotten, and incomplete homework. The standard punishment involved missing recess and, depending on the type of assignment, receiving a lower grade.

\section{Exemptions from Homework Rules}

To avoid conflict with higher-SES White families and protect critical support, teachers selectively enforced the rules. They did so, in part, by granting exemptions to students whose parents would likely create conflict if their children were held accountable to the rules. Those parents, in turn, were generally higher-SES White "helicopter" parents. Ms. Burns, a 4th-grade teacher, was critical of "helicopter" parents who asked for exemptions from homework rules:

I get, probably, 10 emails a day from parents. Mom or dad will write and say, "[My child] didn't do their homework because they had dance last night." I'm sorry they had dance last night, but ... really? Mom and dad are trying to save them from everything and it's really going to backfire.

In practice, however, Ms. Burns usually granted those requests. To explain that decision, Ms. Burns pointed to the case of Edward Stephens, a higher-SES White student with an Individualized Education Plan (IEP) for Attention Deficit Disorder (ADD) who regularly forgot his homework or failed to complete it correctly. Ms. Burns told me about her ongoing "homework battle" with Edward's mother:

Edward forgets his homework. And so I tell Ms. Stephens that Edward will have to stay in for recess. And she writes back, [including the principal in the email, saying]: "I really believe that recess is a time for them to run around. I don't believe in staying in." [And the principal conceded]. So Edward has no consequences. If something happens, he'll go home and tell mom, and she'll write an email to the principal. And she's threatening with words like "advocate,"13 "lawyer," all these things. And because [Ms. Stephens is] saying that, because she's using the fear factor-has Edward stayed in for recess? No. He hasn't had to face those consequences. 
By using the "fear factor," higher-SES White "helicopter" parents demonstrated their willingness to push back if teachers tried to enforce the rules. That possibility of conflict, in turn, led teachers to strategically (not) enforce homework rules.

Under a strategic-enforcement model, teachers also granted exemptions to families on whom they relied most heavily for support. For example, as higher-SES White mother Ms. Corsaro told me in an interview, her frequent presence as a PTO volunteer made it easy to break rules about dropping off her children's forgotten assignments:

I think Maplewood has a pretty strong policy about that [parents picking up and dropping off left materials], that they don't want you to do it. . . . [And] I think I've done a disservice to my kids by being so involved in school. Like, they forget things. . . And generally I'm there almost every day, so I do drop things off. And so there's no consequence... I mean, I really do think it's a valuable lesson [to face consequences], that that's the best way to learn. But I don't want them to suffer.

When PTO parents like Ms. Corsaro came to school, I never saw office staff question why they were there-in some cases, they were even allowed to skip normal sign-in procedures. I also never saw a teacher prevent a PTO parent from dropping off an assignment their child forgot at home. Despite official rules, Maplewood willingly granted exemptions to the higher-SES, White "helicopter" parents who provided critical support.

Teachers justified these occasional exemptions by pointing to the fact that higher-SES, White students with "helicopter" parents generally complied with homework rules. Drew Bertrand, for example, was a higher-SES, White student who got mostly As in school and whose mother volunteered with the PTO. One morning in 5th grade, Drew realized he forgot his language arts project:

Drew skitters nervously toward Ms. Hudson's desk. As Ms. Hudson looks up from her computer, Drew shifts his gaze to the floor. Breathlessly, he explains that he left his project in his mom's car. Pausing, Drew asks quickly: "Can I call my mom and ask her to bring it back in?" Ms. Hudson smiles warmly, reassuring Drew that "it's okay" and that he can call his mom. Drew, however, is still breathing hard, seemingly on the verge of tears. Ms. Hudson gets up and glides quickly around her desk toward Drew. Leaning down, Ms. Hudson rests her hands softly on Drew's shoulders, explaining: "That's what responsibility gets you. There's a trust, okay?” Drew looks up, meeting Ms. Hudson's gaze. He gives her a wobbly smile, then exhales: "Thank you so much!” Ms. Hudson waves a hand toward the classroom phone, adding: "Don't worry about it." 
Like many other higher-SES, White parents, Drew's mother took a "helicopter"-like approach to homework help. She would sit with him while he did homework, check that it was correct, and (usually) make sure it was in his backpack. Furthermore, in the rare cases where Drew forgot his homework, Ms. Bertrand was willing and able to drop it off for him — even though that was against the rules. That support allowed Drew to comply (or at least appear to comply) with rules by getting his homework done correctly and on-time. That apparent compliance led Ms. Hudson to see Drew as "responsible" and thus more worthy of occasional exemptions from rules.

Most higher-SES, White parents had the resources to provide "helicopter"-like support (see also HaleyLock and Posey-Maddox 2016; Hamilton 2016; Horvat et al. 2003; Lareau 2000, 2011; Milkie and Warner 2014; Nelson 2010; Posey-Maddox 2014; Schieman et al. 2018), but not all privileged parents intervened in these ways.14 Teachers, in turn, did not always perceive those families as contentious enough, important enough, or compliant enough to be worthy of exemptions from rules. Kyle Muller, for example, was an average-achieving, higher-SES, White student whose parents were less connected to other Maplewood families, in part, because they both worked long hours and spent more than an hour each way commuting to their jobs. After school, Kyle's older brother was supposed to help with homework, but Kyle came to school at least once a week without his homework done. Kyle's teachers mostly gave him low ratings for homework, and they blamed Kyle's homework struggles on what Ms. Hudson called a "lack of parental oversight." Kyle's teachers also tended to be harsh with Kyle about his homework struggles. One morning, after checking homework, Ms. Hudson called Kyle up to her desk:

Before Kyle can say anything, Ms. Hudson snaps: "You're staying in for recess." As Kyle shifts his gaze to the floor, Ms. Hudson continues, explaining that not having homework is "unacceptable." Shaking her head in exasperation, Ms. Hudson concludes brusquely: "You better get yourself together." Kyle says nothing. He just nods and goes back to his seat.

Ms. Hudson did not take pity on Kyle; instead, she held him accountable to the rules. That lack of sympathy contrasted sharply with how Ms. Hudson treated other higher-SES, White students. Interestingly, Kyle was the only student in the study who later transferred to private school. Explaining that decision, Kyle's mother said the public schools "expect too much of parents" and "have too many rules."

\section{Accountability to Homework Rules}

Most of the lower-SES White families did not have the resources to provide "helicopter"-like support for their children (see also Edwards 2004; Haley-Lock and Posey-Maddox 2016; Hamilton 2016; Lareau 2000, 2011; Villalobos 2014). Thus, teachers rarely perceived those families as contentious enough, important enough, or compliant enough to warrant exemptions from rules. Lower-SES White student Zach Campitello, for example, faced considerable struggles with homework. Zach's Attention Deficit Disorder (ADD) made it difficult for him to remember his homework and get it done. As Zach explained: 
"I'm pretty much wiped out at the end of the school day, and I just don't wanna do anything. I don't feel like concentrating." Zach also had an Individualized Education Plan (IEP) that required his teachers to check that his homework was in his backpack before going home. Some days, however, Zach would still come home without his homework. This made Zach's mother extremely upset, as she told me in an interview:

[Mr. Fischer was supposed to be checking Zach's backpack]. That never happened. So I said something to Mr. Fischer at a meeting, like, "I thought you were going through Zach's bookbag." And he's like, "Zach showed it to me and I assumed he put it in there. There are children in the class that need my help more than Zach. Zach needs to learn to be responsible." I was pissed. I was so mad.

Despite being "pissed," Ms. Campitello waited months (until the next scheduled parent-teacher conference) to discuss the situation with Mr. Fischer, and she never escalated her complaint to the principal or threatened legal action. Meanwhile, Zach continued to struggle with homework. Close to tears, Ms. Campitello recalled:

Zach actually threatened to harm himself if we didn't back off on the homework. I don't know if he was manipulating us, but he just wouldn't do it. Like I said, it was really, really hard.

When I talked to Mr. Fischer about the situation, he was dismissive of Ms. Campitello's concerns, saying Ms. Campitello just needed to work harder to teach Zach responsibility with homework. Mr. Fischer did not seem to fear conflict with Ms. Campitello, and he did not seem to feel compelled to grant Zach exemptions from homework rules, even when those exemptions were part of Zach's IEP. Instead, Mr. Fischer regularly kept Zach in for recess, gave him zeros on missed assignments, and chastised him in front of the class for not being more responsible with homework.

Teachers also avoided granting exemptions to students whose families they did not perceive as an important source of support. The lower-SES White parents I interviewed cared deeply about their children's education (see also Calarco 2014, 2018). Teachers, however, had limited knowledge of students' home lives. They relied on what they could see-emails, phone calls, conference attendance, volunteering, donations, and even students' homework - to make judgments about parents' support. As 3rd-grade teacher Ms. Campbell told me in an interview:

I find, the students that need the most assistance and have the most problems - their parents show the least amount of interest. They don't come in [for parent-teacher conferences]. Email - they might respond or not at all. It's just not a priority. So that speaks volumes to me. 
Such assumptions led teachers to write off lower-SES White children with non-"helicopter" parents. As 4th-grade teacher Mr. Cherlin explained:

I feel like there's a pocket here - a lower-income pocket. And that trickles down to less support at home, homework not being doing, stuff not being returned and signed. It should be almost fifty-fifty between home and school. And if they don't have the support at home, there's only so far I can take them. If they're not gonna go home and do their homework, there's just not much I can do.

Because lower-SES White parents struggled to demonstrate highly-visible and "helicopter"-like involvement in school, teachers did not perceive lower-SES White families as a valued source of support for the school.

Those perceptions, in turn, allowed teachers to justify holding lower-SES White students accountable to rules. Shawn Marrone, for example, was a lower-SES White student who got Bs and Cs in school. Shawn's mother was a home daycare provider-from 7:30am to 6:30pm (and sometimes later), she watched other people's children in her home while also caring for her ailing father. During our interview, I asked Ms. Marrone what homework was like for Shawn, who had just finished 5th grade. She sighed and explained:

[The problem is] getting him to do it. And part of it I guess is my fault, too. We've never really had "homework time." Like, some people say, "Come home after school and do your homework." Well, we can't do homework after school, because I have tons of kids [that I'm babysitting], and kids are being picked up, and then once kids are picked up, I'm making dinner. So sometimes, I would say to [Shawn], "Okay, come sit in the kitchen." But then Shawn would nod off. Or grandpa would need Shawn to help him with something. So then it would be, "All right, we're doing it [homework] definitely after dinner." And at that point, I would say, "Come on Shawn, we don't have time. Get your homework done." But it would be $8: 30$ or 9 by that point. So it just wouldn't get done. He does know how to do the homework. It's just finding the time. And as I said, I can't even blame him completely. It's the way our household is. It's a little crazy.

Because of the high demands on her time, Ms. Marrone struggled to support Shawn with homework and get involved at school. In April of Shawn's 4th-grade year, Shawn's teacher told me he had never met or even heard from Shawn's parents, leading him to conclude that "school just isn't a priority in their house." Ultimately, because Shawn's family was not able to provide "helicopter"-like support, Shawn's teachers did not seem compelled to grant him exemptions from rules. Instead, Shawn had to stay in for recess at least a few times a month because of homework, and his teachers gave him low ratings for homework completion. 
Teachers used lower-SES students' more frequent struggles with rule compliance to justify not exempting them from rules. Cody Dauber, for example, was a lower-SES mixed-race student who got mostly Cs and Ds and received very low ratings for homework effort. When Cody read the wrong section of his book for homework, Ms. Hudson did not grant him lenience:

Glowering at Cody, Ms. Hudson huffs: "It is obvious that you did not do the reading." Cody starts to interject, protesting: "But!" Ms. Hudson cuts him off, snapping: "Cody, be quiet." Cody slumps back in his chair, folding his arms frustratedly across his chest and grumbling: "I thought we were supposed to read Chapter 8, so I read Chapter 8." Ms. Hudson sniffs and raises one eyebrow skeptically. After a moment, she responds sharply: "Well, the first thing is to make sure you have the assignment right. That's responsibility." As Cody frowns at his desk, Ms. Hudson continues, explaining that Cody will have to come in for recess to read the correct chapter, instead.

Cody regularly had problems with homework - he left his assignments at home, did the wrong problems, or failed to finish them all. Cody's teachers used that apparent lack of compliance as evidence that Cody was not "responsible" enough to deserve exemptions from rules.

Many lower-SES parents at Maplewood struggled to provide "helicopter"-like support with homework (see also Edwards 2004; Haley-Lock and Posey-Maddox 2016; Hamilton 2016; Lareau 2000, 2011; Villalobos 2014), but a few were able to do so. As a result, teachers were more inclined to grant their children exemptions from rules. Among the lower-SES White parents, for example, Ms. Davis was the only stay-at-home mother and the only regular volunteer at school. She had been PTO president at the lower-SES school where her family had lived before moving to Maplewood. Ms. Davis was also the only lower-SES White parent who regularly contacted teachers with questions about homework. As she explained:

[My daughter] Shannon would be in tears: "I don't understand it. It's due tomorrow." And I would try to show to show her the old school way of doing it, and she'd say: "That's not the way! I know it's not the way!" So, I would just write a note on her homework and say: "Shannon didn't understand this. I didn't understand this. I don't want anyone to be frustrated that it's not done." And I would ask her at the end of the day: "Did Mr. Potter talk to you?" And, she would say "Yeah, he explained it to me. I can do it tonight, instead." And he never called her out on it or anything.

Compared to other lower-SES White parents, Ms. Davis had more time to help her children at home and more confidence intervening at school. Because of those interventions, Shannon's teachers seemed compelled to grant Shannon more leeway with homework rules. Despite these within-SES variations, however, and because higher-SES White parents had more resources to support "helicopter"-like 
interventions in school, teachers ultimately granted (and seemed to feel justified in granting) more rule exemptions to higher-SES White students than to their lower-SES peers.

\section{PRIVILEGE-APPEASEMENT AND INEQUALITIES IN SCHOOL}

Teachers likely did not intend to treat students unfairly, but their rule-enforcement decisions contributed to inequalities in student discipline, with higher-SES students facing fewer disciplinary sanctions than lower-SES students. Those inequalities were particularly apparent one morning in Mr. Potter's 5th-grade class:

Just after the bell, Mr. Potter tells his students to take out their gym homework. Elliot (higher-SES, White) and Steve (higher-SES, Asian American) immediately ask to "borrow" or "see" friends" homework and copy the answers. Julie (higher-SES, White) instead asks Mr. Potter for help. After some playful banter, he tells her: "My solution would be to look off of someone else's paper, using it to get the questions, but without copying." Julie then scampers over to Maureen, asking to "borrow" her homework and quickly copying the answers.

Lucy (lower-SES, White) also did not have her homework. Lucy, however, did not try to copy a friend's homework or ask Mr. Potter for help; instead, she went to gym without her homework, and she was the only student who faced any consequences:

Lucy hovers by the gym door as the other students hand their homework to the teacher and settle on the bleachers. Eventually, the teacher notices Lucy and asks: "Homework?" Lucy shrugs, looking at the ground. The teacher scowls and roars: "You don't have it?!" Lucy squirms but says nothing. The teacher points toward the hallway, growling: "To the principal's office!" Lucy looks up, wide-eyed. Seeing Lucy's face, the teacher laughs heartily. "No," he explains, "I'm just kidding about the principal. But you will have to stay in for recess to get it done." Lucy lets out a shaky breath. She nods and slinks quietly over to the bleachers to join the rest of the class.

Maplewood did not keep records of classroom discipline, but my observations showed that, compared to higher-SES White students, lower-SES White students were more often verbally reprimanded and kept in for recess because of problems with homework. Those students sometimes used their missed recesses to complete homework, but missing recess prevented them from exercising and playing with friends and sometimes led to teasing from classmates. Essentially, teachers' unequal rule enforcement exacerbated disciplinary inequalities and inequalities in students' school experiences more generally. 
Teachers' homework enforcement decisions also reinforced inequalities in teachers' evaluations of students. Even when higher-SES White "helicopter" parents were doing their children's homework for them, their children still received high ratings for homework effort and good grades on assignments. For example, when higher-SES White student Tyler Matthews had trouble completing a "research paper" in 5th grade, his mother intervened. As Ms. Matthews recalled:

It was supposed to be a research paper - a factual paper. And he wrote it, and it had a lot of opinion in it. And he had a very difficult time taking the opinion out of the paper and realizing that it needed to be based off fact. And he was very frustrated. ... I mean, he ended up doing fine, but it was really difficult. I had to take him step by step through the whole thing, because he didn't even know how to get the facts. ... He didn't know how to cite it. So it was tough. I hated that project. I hate homework.

Ms. Matthews "hated" homework, but her intervention ensured Tyler got a good grade and that he maintained his high ratings for homework effort. Similarly, when higher-SES White mother Ms. Giordano saw her daughter Gina's grades slipping from As to Bs and Cs, she began doing Gina's homework for her. As Ms. Giordano explained:

I help her a lot with homework. I try to maybe re-explain things, like, things she might not understand. Like, if she's struggling, I try to teach her a different way. I understand that Gina is a very visual child but also needs to hear things, too. I know that when I'm reading it, and I'm writing it, and I'm saying it to her, she comprehends it better. Her reading skills are better if I'm reading to her.

After Ms. Giordano started doing the homework for Gina, Gina's grades improved, and her teachers gave her higher ratings for "homework effort."

Even when teachers strongly suspected that higher-SES White "helicopter" parents were doing children's homework, they did not deduct points or give students lower ratings for homework effort. While walking to lunch, for example, Mr. Fischer told me that Ms. Becker, an extremely involved, higher-SES White "helicopter" parent, was doing her son Nate's homework:

Mr. Fischer continues, explaining that Ms. Becker does Nate's homework "not because he can't do it," but because Nate gets "stressed out and anxious." Mr. Fischer waves a hand, as if it to dismiss the idea that Nate is too anxious. He adds, almost sneering, that Ms. Becker tends to "over-manage" everything Nate does, which limits Nate's ability to develop any "independence." Mr. Fischer calls this a "Helicopter Mom Thing," adding that Ms. Becker worries about Nate having too much work to do. 
Mr. Fischer was privately critical of Ms. Becker for doing Nate's homework. Yet, because Ms. Becker was constantly emailing Mr. Fischer with requests and complaints, and because she regularly escalated those requests and complaints to the principal, Mr. Fischer seemed reluctant to hold her or Nate accountable to the rules. Nate got high ratings for homework effort, and I never saw Mr. Fischer take points off Nate's homework or make Nate stay in for recess for failing to complete homework on his own.

These patterns of inequality in teachers' evaluations of students could also be seen in the data I collected from students' report cards, which included teachers' ratings of student homework effort. As Figure 1 shows, higher-SES White students' homework effort scores were higher than those of lower-SES White students. (Appendix Table A1 shows similar SES patterns for the full sample, which includes Latinx and Asian American students.) Figure 1 also illustrates that students with higher homework ratings, on average, earned better grades. These descriptive data are not intended to make causal claims about the impact of homework or homework exemptions on student achievement. However, they do align with research showing that teachers consider homework when assigning grades (McMillan et al. 2002) and that homework benefits higher-SES but not lower-SES students (Daw 2012; Rønning 2011).

\section{[FIGURE 1 ABOUT HERE]}

\section{DISCUSSION}

Summary of Findings

This study asks how schools' dependence on privileged families influences their enforcement of rules. Using evidence from an ethnographic study of a primarily White, socioeconomically diverse public elementary school, I find that privilege-dependence led Maplewood to appease higher-SES White "helicopter" parents, even when doing so contradicted the school's stated goals. Teachers believed in the importance of student independence with homework, and they set homework rules that, at least in theory, rewarded such independence. However, teachers worried that strictly enforcing those rules would lead to conflict with higher-SES White "helicopter" parents and jeopardize support for the school. Thus, teachers selectively enforced rules, granting exemptions to families that, by virtue of their "helicopter"-like involvement, were perceived as both most contentious and most important for support. Teachers also justified those rule exemptions by pointing to the fact that higher-SES White students with "helicopter" parents generally complied with rules. However, because lower-SES White parents had fewer resources to support "helicopter"-like involvement in school (see also Edwards 2004; Haley-Lock and PoseyMaddox 2016; Hamilton 2016; Lareau 2000, 2011; Villalobos 2014), teachers rarely viewed lower-SES White children as worthy of exemptions from homework rules. Those unequal rule exemptions appeared to reinforce inequalities in teachers' discipline and evaluation of students.

Future research should look for a similar link between privilege-dependence and rule enforcement in other school settings and in other organizations more generally. That said, existing research in other 
public and private schools (Khan 2012; Lewis and Diamond 2015; Lewis-McCoy 2014; Morris and Perry 2016), as well as in hospitals (Gage-Bouchard 2017; Gengler 2014) and criminal justice systems (Jacques and Wright 2015; Mohamed and Fritsvold 2011), has also found evidence of privileged people being granted special favors and exemptions from rules. Given those findings, it seems that privilege-

dependence likely generates unequal rule enforcement across a wide range of organizational settings.

Unlike prior research on rules and inequality, however, these findings also clarify that organizations do not automatically grant rule exemptions to all privileged people they serve. Instead, and possibly for reasons of organizational legitimacy (Johnson, Dowd, and Ridgeway 2006; Meyer and Rowan 1977), organizations make strategic decisions about when to enforce rules. Schools, for example, appear to look for evidence of conflict, support, and compliance when deciding who "deserves" lenience. As a result, schools grant more exemptions to families with "helicopter" parents (most of whom are higher-SES and White) than to families without "helicopter" parents. Those strategic decisions, in turn, are consistent with what we would expect given prior insights from organizational theory (Martin et al. 2013; Meyer and Rowan 1977; Weick 1976), cultural capital theory (Bourdieu and Passeron 1990; Lamont and Lareau 1988; Lareau and Weininger 2003), and research on within-SES variations in parent involvement in school (Haley-Lock and Posey-Maddox 2016; Hamilton 2016).

\section{Implications for Work on Inequality in Organizations}

This study also heeds the call for more research on inequalities in organizations (Abrutyn and Turner 2011; King 2017; Martin et al. 2013; Ray 2019; Tomaskovic-Devey and Avent-Holt 2016). As we see here, inequalities can result from organizational processes, not just individual behaviors. When organizations are privilege-dependent, they can be compelled to ignore their own stated goals and to act in ways that reinforce larger patterns of inequality. In doing so, organizations demonstrate bias not only against people from marginalized groups but also in favor of people from privileged groups (Cucchiara 2013; Hamilton 2016; Lewis and Diamond 2015; Lewis-McCoy 2014; Tilly 1999; Tompkins-Stange 2016).

These findings should urge scholars to question explanations for inequality focusing on the "deficits" of marginalized groups and to pay greater attention to power- and privilege-based explanations (Bourdieu 1984; Bourdieu and Passeron 1990; Tilly 1999). With respect to homework, for example, we saw that privileged parents' resources facilitated the kind of "helicopter"-like involvement that gave their children a considerable (and arguably unfair) advantage in school. Teachers, in turn, justified giving leeway to the children of "helicopter" parents because they perceived those children and their parents as putting a high "priority" on schooling and demonstrating a high level of "responsibility" with homework. Those beliefs, however, were based only on what teachers could see: "helicopter" parenting and homework completion. Teachers did not account for the fact that "helicopter" parenting and homework completion required resources most lower-SES White families did not have. These findings reveal how easy it is for people (even well-meaning teachers) to see inequalities as a "deficit" problem, and they point to the importance of instead considering how inequalities are generated by the actions of organizations and the privileged people they serve. 


\section{Policy Implications}

Along those lines, this study also questions standard policy assumptions about parent involvement in school. Given decades of research linking parent involvement to student achievement (Lee and Bowen 2006; Robinson and Harris 2014; Sui-Chu and Willms 1996), 15 educators and policymakers typically call on parents, and especially lower-SES parents and parents of color, to be more involved in school (Epstein et al. 2008; Pomerantz, Moorman, and Litwack 2007). As we see here, however, those calls ignore barriers that limit involvement among families from marginalized groups (Collins 2005; Diamond and Gomez 2004; Dow 2019; Haley-Lock and Posey-Maddox 2016; Hamilton 2016; Haskins and Jacobsen 2017; Horvat et al. 2003; Klugman, Lee, and Nelson 2012; Lareau 2000; Posey-Maddox and Haley-Lock 2016).16 By calling for greater involvement despite these barriers, educators and policymakers set many parents up to fail. As this study shows, educators use parents' compliance with their unfair expectations to make further unfair judgments about how much parents "prioritize" education and about parents' value to the school. Thus, I would urge educators and policymakers to recognize how expectations for parent involvement advantage higher-SES, White "helicopter" parents, and to ask whether promoting "helicopter"-style involvement might do more harm than good.

By revealing how schools' dependence on "helicopter" parents gave higher-SES White students unfair advantages with homework, this study also helps explain why homework has unequal benefits for students. Some studies link homework to learning and achievement (Bempechat 2004; Cooper et al. 2006; Farkas et al. 1990; Vatterott 2011), yet other studies find that higher-SES students disproportionately benefit from homework (Daw 2012; Rønning 2011). As we see here, those unequal benefits might reflect the fact that homework-related processes favor higher-SES White students. By virtue of their parents' resources and "helicopter"-like support, higher-SES White students were generally better able to comply with (or appear to comply with) homework rules. Furthermore, even when those resources failed to prevent problems with homework, higher-SES White students could rely on their parents to help them avoid consequences. Lower-SES White students, however, had more difficulty completing homework, which resulted in more disciplinary sanctions and more negative evaluations from teachers. Thus, even if completing homework has some academic benefits for lower-SES students, those benefits might be offset by the negative academic consequences associated with being disciplined and underestimated in school (Gregory, Skiba, and Noguera 2010; Jussim and Harber 2005; Morris and Perry 2016).

Eliminating elementary school homework could reduce those inequalities, and some schools have gone that route (Tate 2018). That said, I also found similar patterns of unequal enforcement with attendance rules (i.e., which students were granted "excused" absences), rules regarding teacher assignment and course placement (i.e., which students were assigned to the "best" teachers and which students were placed in advanced classes), and rules regarding classroom snack and behavior policies (see also Lewis and Diamond 2015; Lewis-McCoy 2014; Morris 2005). In each case, teachers and administrators used families' perceived contentiousness, supportiveness, and compliance to determine who "deserved" exemptions from rules. As with homework rules, I found that those processes favored higher-SES White students with "helicopter" parents. 
Ultimately, if educators and policymakers want to reduce inequalities, this study suggests that a more effective solution would go beyond individual rules and beyond individual schools or parents. As long as schools are dependent on privileged families, those families will be able to use their privilege to "hoard opportunities" (Tilly 1999), and schools will be unable to stop them-at least without risks to their own social and economic status. Privilege-dependence is a structural problem, and it requires structural solutions. That includes policies to level the playing field with respect to families' resources (e.g., income, wealth, time, job flexibility, educational attainment, and access to well-funded schools). It also includes policies that alleviate schools' dependence on privileged families - reducing reliance on standardized testing as a measure of "quality" in schools; decoupling school funding from local wealth; and requiring revenue sharing for PTOs. Of course, those policies are not an easy sell, and changing privilege-favoring policies is even more difficult when policymakers are privilege-dependent (Heerwig 2018; Scarrow 2007). Without such policies, however, schools will remain dependent on privileged families, and privileged families will get to both make the rules and break the rules without consequence. 


\section{APPENDIX}

Table A1. Homework Effort Ratings,a GPA,b and Test Scoresc: Means by Grade Level, Race/Ethnicity, SES, and Gender

\section{APPENDIX}

Table A1. Homework Effort Ratings, ${ }^{a}$ GPA, ${ }^{b}$ and Test Scores ${ }^{\mathrm{c}}$ : Means by Grade Level, Race/Ethnicity, SES, and Gender

\begin{tabular}{|c|c|c|c|c|c|c|c|c|c|c|}
\hline & \multicolumn{2}{|l|}{ Grade 5} & \multicolumn{2}{|l|}{ Grade 4} & \multicolumn{2}{|c|}{ Grade 3} & \multicolumn{4}{|c|}{$\begin{array}{c}\text { Grades and Test Scores } \\
\text { (Grade 5) }\end{array}$} \\
\hline & Homework & $N$ & Homework & $N$ & Homework & $N$ & GPA & $\begin{array}{l}\text { Math } \\
\text { RIT }\end{array}$ & $\begin{array}{c}\text { Reading } \\
\text { RIT }\end{array}$ & $N$ \\
\hline White, Higher-SES Girls & 3.45 & 19 & 3.89 & 18 & 3.29 & 17 & 3.62 & 224 & 223 & 19 \\
\hline White, Higher-SES Boys & 3.29 & 19 & 3.73 & 17 & 3.11 & 14 & 3.64 & 228 & 220 & 19 \\
\hline White, Lower-SES Girls & 3.04 & 7 & 3.31 & 7 & 2.8 & 6 & 3.18 & 214 & 208 & 7 \\
\hline White, Lower-SES Boys & 2.54 & 7 & 2.83 & 7 & 2.97 & 6 & 2.75 & 220 & 213 & 7 \\
\hline Latinx, Lower-SES Girls & 2.75 & 1 & 3.5 & 1 & 3 & 1 & 2.75 & 211 & 217 & 1 \\
\hline Latinx, Lower-SES Boys & 3 & 3 & 3.33 & 3 & 2.5 & 3 & 3.08 & 210 & 213 & 3 \\
\hline Mixed Race, Higher-SES Boys & 2 & 1 & 2.5 & 1 & 3 & 1 & 3.5 & 232 & 227 & 1 \\
\hline Mixed Race, Higher-SES Boys & 1.75 & 1 & 1.33 & 1 & 2.33 & 1 & 1.5 & 215 & 214 & 1 \\
\hline Asian American, Higher-SES Girls & 3.75 & 1 & 4 & 1 & 4 & 1 & 4 & 236 & 226 & 1 \\
\hline Asian American, Higher-SES Boys & 3.25 & 2 & 4 & 1 & 4 & 1 & 3.63 & 232 & 211 & 2 \\
\hline
\end{tabular}

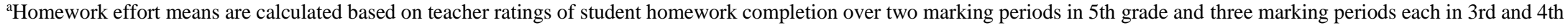
grade. Each marking period, students received two homework scores, one from their regular classroom teacher and one from their ability-grouped math teacher. In each marking period, students could receive a "commendable" (4), "satisfactory" (3), "needs improvement" (2), or "unsatisfactory" (1) rating from each teacher. Scores for each student were summed across marking periods (within a given year) and then divided by the number of scores to produce a mean homework score for the student in that year (out of 4 ). Within each group, mean scores were then summed and divided by the number of students in the group to produce a mean score for that group in that year. The number reported is the mean score for each group 'GPA (grade point average) is calculated based on students' grades in four subjects (math, language arts, science, and social studies) over two marking periods (Fall and Winter) in 5th grade. In each marking period, students could receive an A (4), B (3), C (2), or D (1) for each subject. Mean GPAs for each student and each group were calculated using the same procedures described for calculating homework means. The table presents the mean GPA for each group.

'Test scores are calculated based on students' Reading RIT and Math RIT scores on the MAP Growth Assessment, a computerized adaptive learning assessment, which students took at the beginning of 5 th grade. The table presents the mean score for each group. 


\section{Acknowledgments}

A previous version of this manuscript was presented at the 2019 meeting of the American Sociological Association. I am deeply grateful to Tim Hallett, Koji Chavez, and Katie Beardall, as well as to the editors and anonymous reviewers, for their feedback and for helping me to clarify and strengthen my arguments. I also appreciate my family's patience with my limited parent involvement while getting this paper done.

\section{Funding}

The research reported here was supported by the Department of Sociology at the University of Pennsylvania, by the Gertrude and Otto Pollack Fellowship, and by the Institute of Education Sciences, U.S. Department of Education, through Grant R305C050041-05 to the University of Pennsylvania. The opinions expressed are those of the author and do not represent views of any supporting agencies.

\section{Notes}

1. All names are pseudonyms. Some identifying details have been changed to increase confidentiality.

2. In the United States, there is evidence of privilege-dependence in healthcare organizations (Arneill and Devlin 2002; Ryan 2016; Wright and Perry 2010), philanthropic organizations (McGoey and Thiel 2018; Silver 2007; Tompkins-Stange 2016), political campaigns (Heerwig 2018; Scarrow 2007), and, although possibly to a lesser extent, cultural and consumption-oriented organizations such as restaurants (Lehman, Kovács, and Carroll 2014; Zukin, Lindeman, and Hurson 2017) and retailers (Chao and Schor 1998; Geiger-Oneto et al. 2013; Joy et al. 2012).

3. These inequalities are exacerbated by the socioeconomic and racial segregation of U.S. communities and schools (Fiel 2013; Owens 2016; Reardon and Owens 2014) and by racist policies that created and perpetuate wealth gaps between Black and White communities (Addo, Houle, and Simon 2016; Oliver and Shapiro 2006; Seamster and Charron-Chénier 2017).

4. Scholars have critiqued institutional theory for its lack of attention to inequality in organizations (Abrutyn and Turner 2011; Acker 2006; King 2017; Martin et al. 2013; Ray 2019; Tomaskovic-Devey and Avent-Holt 2016).

5. Research shows that being assigned homework (Rønning 2011) and spending more time on homework (Daw 2012) are associated with greater academic benefits for higher-SES than for lower-SES students. 
6. Socioeconomic status has been measured in myriad ways (Lareau and Conley 2010). Following research on social class and parenting (Lareau 2011), I focus on parents' educational and occupational status. Higher-SES students had at least one parent with both a four-year college degree and a professional or managerial job, with household incomes averaging \$120,000 annually. Lower-SES students typically had parents with high school diplomas who worked in blue-collar or service jobs, with household incomes averaging $\$ 35,000$ annually. Roughly 13 percent of students received free or reducedprice lunch.

7. In the interest of brevity, I use the term "White" to refer to students and parents who identified as White and did not identify as Hispanic or Latinx. Racially, the Latinx families who completed the survey all identified as either White or "other."

8. With the help of the English Language Learning (ELL) teacher, I created a Spanish-language survey, which some of the Latinx families completed instead of the English version.

9. The school record data include three marking periods each from 3rd and 4th grade and two marking periods from 5th grade. Final marking period records for 5th grade were not yet available during data collection.

10. At the time of the study, the school district had a total annual budget of nearly $\$ 19,000$ per student.

11. Teacher salaries were based on teachers' years of experience, educational attainment, and continuing education credits. The district subsidized teachers' costs for advanced degrees and continuing education credits.

12. Those score gaps are reflected in the fact that Maplewood receives substantially lower GreatSchools.org ratings for "equity" than for "academics."

13. Parent advocates are non-attorney legal professionals who can be hired to help mediate disputes between families and schools.

14. Some higher-SES White parents had extremely busy work schedules that limited their involvement (see also Haley-Lock and Posey-Maddox 2016; Muller 1995); others, as upwardly mobile parents, were ambivalent about hovering (see also Roksa and Potter 2011; Streib 2015). 
15. Some scholars, however, argue that the benefits of parent involvement are overstated or that they are explained by the fact that higher-SES parents are the ones most likely to be involved (Domina 2005; McNeal 1999; Muller 1995).

16. This study focuses on White, non-Hispanic/Latinx parents, but I also found structural limits on lowerSES Latinx parents' involvement in school. Through interviews with teachers, I learned that language barriers made it difficult for many Latinx parents to help with homework. The school created an afterschool homework program for those students. However, as I learned from the teachers, many Latinx parents did not have valid drivers' licenses and thus could not send their children to the after-school program, because driving to pick them up after school meant risking being pulled over by local police officers who were targeting their neighborhoods. Because of these transportation-related challenges, and as I documented in my fieldnotes, Latinx students also could not ask their parents to drop off assignments they left at home. 


\section{References}

Abrutyn, Seth, and Jonathan H. Turner. 2011. "The Old Institutionalism Meets the New Institutionalism." Sociological Perspectives 54(3):283-306.

Acker, Joan. 2006. "Inequality Regimes: Gender, Class, and Race in Organizations." Gender \& Society 20(4):441-64.

Addo, Fenaba R., Jason N. Houle, and Daniel Simon. 2016. "Young, Black, and (Still) in the Red:

Parental Wealth, Race, and Student Loan Debt." Race and Social Problems 8(1):64-76.

Arneill, Allison B., and Ann Sloan Devlin. 2002. "Perceived Quality of Care: The Influence of the Waiting Room Environment.” Journal of Environmental Psychology 22(4):345-60.

Baker, David P., and David L. Stevenson. 1986. "Mothers' Strategies for Children's School Achievement: Managing the Transition to High School." Sociology of Education 59(3):156-66.

Barrow, Lisa. 2002. "School Choice through Relocation: Evidence from the Washington, D.C. Area." Journal of Public Economics 86(2):155-89.

Bempechat, Janine. 2004. "The Motivational Benefits of Homework: A Social-Cognitive Perspective." Theory into Practice 43(3):189-96.

Bourdieu, Pierre. 1984. Distinction: A Social Critique of the Judgement of Taste. New York: Routledge Kegan \& Paul.

Bourdieu, Pierre, and Jean-Claude Passeron. 1990. Reproduction in Education, Society and Culture. Thousand Oaks, CA: Sage.

Braunstein, Ruth, Brad R. Fulton, and Richard L. Wood. 2014. "The Role of Bridging Cultural Practices in Racially and Socioeconomically Diverse Civic Organizations." American Sociological Review 79(4):705-25. 
Calarco, Jessica McCrory. 2018. Negotiating Opportunities: How the Middle Class Secures Advantages in School. New York: Oxford University Press.

Calarco, Jessica McCrory. 2014. "Coached for the Classroom: Parents' Cultural Transmission and Children's Reproduction of Educational Inequalities," American Sociological Review 79, no. 5: 10151037.

Chao, Angela, and Juliet B. Schor. 1998. "Empirical Tests of Status Consumption: Evidence from Women's Cosmetics.” Journal of Economic Psychology 19(1):107-31.

Collins, Patricia Hill. 2005. "Black Women and Motherhood." Pp. 149-59 in Motherhood and Space: Configurations of the Maternal through Politics, Home, and the Body, edited by S. Hardy and C. Wiedmer. New York: Palgrave Macmillan US.

Condron, Dennis J., and Vincent J. Roscigno. 2003. "Disparities Within: Unequal Spending and Achievement in an Urban School District." Sociology of Education 76(1):18-36.

Cooper, Harris, Jorgianne Civey Robinson, and Erika A. Patall. 2006. "Does Homework Improve Academic Achievement? A Synthesis of Research, 1987-2003." Review of Educational Research 76(1):1-62.

Cucchiara, Maia Bloomfield. 2013. Marketing Schools, Marketing Cities. Chicago: University of Chicago Press.

Daw, Jonathan. 2012. "Parental Income and the Fruits of Labor: Variability in Homework Efficacy in Secondary School.” Research in Social Stratification and Mobility 30(3):246-64.

Diamond, John B., and Kimberley Gomez. 2004. “African American Parents' Educational Orientations: The Importance of Social Class and Parents' Perceptions of Schools." Education and Urban Society 36(4):383-427.

Domina, Thurston. 2005. "Leveling the Home Advantage: Assessing the Effectiveness of Parental Involvement in Elementary School.” Sociology of Education 78(3):233-49.

Dow, Dawn Marie. 2019. Mothering While Black. Berkeley: University of California Press. 
Duke, Nell K. 2000. "For the Rich It's Richer: Print Experiences and Environments Offered to Children in Very Low- and Very High-Socioeconomic Status First-Grade Classrooms.” American Educational Research Journal 37(2):441-78.

Edwards, Margie L. Kiter. 2004. "We're Decent People: Constructing and Managing Family Identity in Rural Working-Class Communities.” Journal of Marriage and Family 66(2):515-29.

Emerson, Robert M., Rachel I. Fretz, and Linda L. Shaw. 2011. Writing Ethnographic Fieldnotes, 2nd ed. Chicago: University of Chicago Press.

Epstein, Diana. 2011. Measuring Inequity in School Funding. Washington, DC: Center for American Progress.

Epstein, Joyce L. 1988. "Homework Practices, Achievements, and Behaviors of Elementary School Students.” Office of Educational Research and Improvement. Washington, DC.

https://eric.ed.gov/?id=ED301322

Epstein, Joyce L., Mavis G. Sanders, Steven Sheldon, Beth S. Simon, Karen Clark Salinas, Natalie R. Jansorn, Frances L. VanVoorhis, Cecelia S. Martin, Brenda G. Thomas, Marsha D. Greenfield, Darcy J. Hutchins, and Kenyatta J. Williams. 2008. School, Family, and Community Partnerships: Your Handbook for Action, 3rd ed. Thousand Oaks, CA: Corwin.

Farkas, George, Robert P. Grobe, Daniel Sheehan, and Yuan Shuan. 1990. "Cultural Resources and School Success: Gender, Ethnicity, and Poverty Groups within an Urban School District." American Sociological Review 55(1):127-42.

Fiel, Jeremy E. 2013. "Decomposing School Resegregation: Social Closure, Racial Imbalance, and Racial Isolation." American Sociological Review 78(5):828-48.

Forsberg, Lucas. 2007. "Homework as Serious Family Business: Power and Subjectivity in Negotiations about School Assignments in Swedish Families." British Journal of Sociology of Education 28(2):20922.

Gage-Bouchard, Elizabeth A. 2017. "Culture, Styles of Institutional Interactions, and Inequalities in Healthcare Experiences.” Journal of Health and Social Behavior 58(2):147-65. 
Geiger-Oneto, Stephanie, Betsy D. Gelb, Doug Walker, and James D. Hess. 2013. “'Buying Status' by Choosing or Rejecting Luxury Brands and Their Counterfeits." Journal of the Academy of Marketing Science 41(3):357-72.

Gengler, Amanda M. 2014. “'I Want You to Save My Kid!': Illness Management Strategies, Access, and Inequality at an Elite University Research Hospital." Journal of Health and Social Behavior 55(3):34259.

Gill, Brian P., and Steven L. Schlossman. 2003. "A Nation at Rest: The American Way of Homework." Educational Evaluation and Policy Analysis 25(3):319-37.

Gill, Brian P., and Steven L. Schlossman. 2004. "Villain or Savior? The American Discourse on Homework, 1850-2003." Theory into Practice 43(3):174-81.

Golann, Joanne W. 2015. "The Paradox of Success at a No-Excuses School.” Sociology of Education 88(2):103-19.

Gregory, Anne, Russell J. Skiba, and Pedro A. Noguera. 2010. "The Achievement Gap and the Discipline Gap: Two Sides of the Same Coin?” Educational Researcher 39(1):59-68.

Hagerman, Margaret. 2018. White Kids: Growing Up with Privilege in a Racially Divided America. New York: NYU Press.

Haley-Lock, Anna, and Linn Posey-Maddox. 2016. "Fitting It All In: How Mothers' Employment Shapes Their School Engagement." Community, Work \& Family 19(3):302-21.

Hallett, Tim, and Marc J. Ventresca. 2006. "Inhabited Institutions: Social Interactions and Organizational Forms in Gouldner's Patterns of Industrial Bureaucracy.” Theory and Society 35(2):213-36.

Hamilton, Laura T. 2016. Parenting to a Degree. Chicago: University of Chicago Press.

Hammersley, Martyn, and Paul Atkinson. 2007. Ethnography: Principles in Practice, 3rd ed. London, UK: Routledge. 
Hasan, Sharique, and Anuj Kumar. 2019. "Digitization and Divergence: Online School Ratings and Segregation in America." SSRN Scholarly Paper, ID 3265316. Rochester, NY: Social Science Research Network.

Haskins, Anna R., and Wade C. Jacobsen. 2017. "Schools as Surveilling Institutions? Paternal Incarceration, System Avoidance, and Parental Involvement in Schooling." American Sociological Review 82(4):657-84.

Hays, Sharon. 1998. The Cultural Contradictions of Motherhood. New Haven, CT: Yale University Press.

Heerwig, Jennifer A. 2018. "Money in the Middle: Contribution Strategies among Affluent Donors to Federal Elections, 1980-2008.” American Journal of Sociology 123(4):1004-63.

Hoover-Dempsey, Kathleen V., Angela C. Battiato, Joan M. T. Walker, Richard P. Reed, Jennifer M. DeJong, and Kathleen P. Jones. 2001. "Parental Involvement in Homework." Educational Psychologist 36(3):195-209.

Horvat, Erin McNamara, Elliot B. Weininger, and Annette Lareau. 2003. "From Social Ties to Social Capital: Class Differences in the Relations between Schools and Parent Networks." American Educational Research Journal 40(2):319-51.

Jackson, Philip W., Robert E. Boostrom, and David E. Hansen. 1993. The Moral Life of Schools. San Francisco, CA: Jossey-Bass.

Jacques, Scott, and Richard Wright. 2015. Code of the Suburb: Inside the World of Young Middle-Class Drug Dealers. Chicago: University of Chicago Press.

Johnson, Cathryn, Timothy J. Dowd, and Cecilia L. Ridgeway. 2006. "Legitimacy as a Social Process." Annual Review of Sociology 32(1):53-78.

Joy, Annamma, John F. Sherry Jr., Alladi Venkatesh, Jeff Wang, and Ricky Chan. 2012. "Fast Fashion, Sustainability, and the Ethical Appeal of Luxury Brands." Fashion Theory 16(3):273-95. 
Jussim, Lee, and Kent D. Harber. 2005. "Teacher Expectations and Self-Fulfilling Prophecies: Knowns and Unknowns, Resolved and Unresolved Controversies." Personality and Social Psychology Review 9(2):131-55.

Kadushin, Charles, Matthew Lindholm, Dan Ryan, Archie Brodsky, and Leonard Saxe. 2005. "Why It Is So Difficult to Form Effective Community Coalitions." City \& Community 4(3):255-75.

Khan, Shamus. 2012. Privilege: The Making of an Adolescent Elite. Princeton, NJ: Princeton University Press.

King, Brayden G. 2017. “The Relevance of Organizational Sociology.” Contemporary Sociology 46(2):131-37.

Klugman, Joshua. 2013. "The Advanced Placement Arms Race and the Reproduction of Educational Inequality.” Teachers College Record 115(5):1-34.

Klugman, Joshua, Jennifer C. Lee, and Shelley L. Nelson. 2012. "School Co-ethnicity and Hispanic Parental Involvement.” Social Science Research 41(5):1320-37.

Krysan, Maria, Kyle Crowder, and Michael D. M. Bader. 2014. "Pathways to Residential Segregation." Pp. 27-63 in Choosing Homes, Choosing Schools, edited by A. Lareau and K. Goyette. New York: Russell Sage Foundation.

Lamont, Michele, and Annette Lareau. 1988. "Cultural Capital: Allusions, Gaps and Glissandos in Recent Theoretical Developments.” Sociological Theory 6(2):153-68.

Lareau, Annette. 2000. Home Advantage: Social Class and Parental Intervention in Elementary Education. New York: Rowman \& Littlefield.

Lareau, Annette. 2011. Unequal Childhoods. Berkeley: University of California Press.

Lareau, Annette, and Dalton Conley, eds. 2010. Social Class: How Does It Work? Reprint edition. New York: Russell Sage Foundation. 
Lareau, Annette, and Kimberly Goyette. 2014. Choosing Homes, Choosing Schools. New York: Russell Sage Foundation.

Lareau, Annette, and Erin McNamara Horvat. 1999. "Moments of Social Inclusion and Exclusion Race, Class, and Cultural Capital in Family-School Relationships.” Sociology of Education 72(1):37-53.

Lareau, Annette, and Elliot B. Weininger. 2003. "Cultural Capital in Educational Research: A Critical Assessment." Theory and Society 32(5-6):567-606.

Lareau, Annette, Elliot Weininger, and Amanda Cox. 2018. "Parental Challenges to Organizational Authority in an Elite School District: The Role of Cultural, Social, and Symbolic Capital." Teachers College Record 120(1):1-46.

Lau, Eva Y. H., Hui Li, and Nirmala Rao. 2011. "Parental Involvement and Children's Readiness for School in China." Educational Research 53(1):95-113.

Leachman, Michael, Kathleen Masterson, and Eric Figueroa. 2017. A Punishing Decade for School Funding. Washington, DC: Center on Budget and Policy Priorities.

Lee, Jung-Sook, and Natasha K. Bowen. 2006. "Parent Involvement, Cultural Capital, and the Achievement Gap among Elementary School Children.” American Educational Research Journal 43(2):193-218.

Lehman, David W., Balázs Kovács, and Glenn R. Carroll. 2014. "Conflicting Social Codes and Organizations: Hygiene and Authenticity in Consumer Evaluations of Restaurants." Management Science 60(10):2602-17.

Leondar-Wright, Betsy. 2005. Class Matters: Cross-Class Alliance Building for Middle-Class Activists. Gabriola Island, BC: New Society Publishers.

Lewis, Amanda E., and John B. Diamond. 2015. Despite the Best Intentions: How Racial Inequality Thrives in Good Schools. New York: Oxford University Press.

Lewis-McCoy, R. L'Heureux. 2014. Inequality in the Promised Land: Race, Resources, and Suburban Schooling. Palo Alto, CA: Stanford University Press. 
Li, Angran, and Daniel Hamlin. 2019. "Is Daily Parental Help with Homework Helpful? Reanalyzing

National Data Using a Propensity Score-Based Approach.” Sociology of Education 92(4):367-85.

Logan, John R., Andrew Foster, Jun Ke, and Fan Li. 2018. "The Uptick in Income Segregation: Real Trend or Random Sampling Variation?” American Journal of Sociology 124(1):185-222.

Logan, John R., Elisabeta Minca, and Sinem Adar. 2012. "The Geography of Inequality: Why Separate Means Unequal in American Public Schools." Sociology of Education 85(3):287-301.

Martin, Andrew W., Steven H. Lopez, Vincent J. Roscigno, and Randy Hodson. 2013. "Against the Rules: Synthesizing Types and Processes of Bureaucratic Rule-Breaking." Academy of Management Review 38(4):550-74.

McGoey, Linsey, and Darren Thiel. 2018. "Charismatic Violence and the Sanctification of the SuperRich.” Economy and Society 47(1):111-34.

McMillan, James H., Steve Myran, and Daryl Workman. 2002. "Elementary Teachers' Classroom Assessment and Grading Practices.” Journal of Educational Research 95(4):203-13.

McNeal, Ralph B. 1999. "Parental Involvement as Social Capital: Differential Effectiveness on Science Achievement, Truancy, and Dropping Out." Social Forces 78(1):117-44.

Meyer, John W., and Brian Rowan. 1977. "Institutionalized Organizations: Formal Structure as Myth and Ceremony.” American Journal of Sociology 83(2):340-63.

Miles, Matthew B., A. Michael Huberman, and Johnny Saldaña. 2013. Qualitative Data Analysis: A Methods Sourcebook, 3rd ed. Thousand Oaks, CA: Sage Publications.

Milkie, Melissa A., and Catherine H. Warner. 2014. "Status Safeguarding: Mothers' Work to Secure Children's Place in the Social Hierarchy." Pp. 66-85 in Intensive Mothering: The Cultural Contradictions of Modern Motherhood, edited by L. Rose Ennis. Ontario, Canada: Demeter Press.

Mohamed, A. Rafik, and Erik Fritsvold. 2011. Dorm Room Dealers: Drugs and the Privileges of Race and Class. Boulder, CO: Lynne Rienner. 
Morris, Edward W. 2005. “'Tuck in That Shirt!' Race, Class, Gender, and Discipline in an Urban School." Sociological Perspectives 48(1):25-48.

Morris, Edward W., and Brea L. Perry. 2016. "The Punishment Gap: School Suspension and Racial Disparities in Achievement.” Social Problems 63(1):68-86.

Muller, Chandra. 1995. "Maternal Employment, Parent Involvement, and Mathematics Achievement among Adolescents." Journal of Marriage and Family 57(1):85-100.

Murray, Brittany, Thurston Domina, Linda Renzulli, and Rebecca Boylan. 2019. "Civil Society Goes to School: Parent-Teacher Associations and the Equality of Educational Opportunity." RSF: The Russell Sage Foundation Journal of the Social Sciences 5(3):41-63.

Nelson, Margaret. 2010. Parenting Out of Control: Anxious Parents in Uncertain Times. New York: NYU Press.

Oliver, Melvin, and Thomas M. Shapiro, eds. 2006. Black Wealth / White Wealth: A New Perspective on Racial Inequality, 2nd ed. New York: Routledge.

Owens, Ann. 2016. "Inequality in Children's Contexts: Income Segregation of Households with and without Children.” American Sociological Review 81(3):549-74.

Patall, Erika A., Harris Cooper, and Jorgianne Civey Robinson. 2008. "Parent Involvement in Homework: A Research Synthesis.” Review of Educational Research 78(4):1039-1101.

Pattillo, Mary, Lori Delale-O'Connor, and Felicia Butts. 2014. "High-Stakes Choosing." Pp. 237-67 in Choosing Homes, Choosing Schools, edited by A. Lareau and K. Goyette. New York: Russell Sage Foundation.

Pomerantz, Eva M., Elizabeth A. Moorman, and Scott D. Litwack. 2007. "The How, Whom, and Why of Parents' Involvement in Children's Academic Lives: More Is Not Always Better.” Review of Educational Research 77(3):373-410. 
Posey-Maddox, Linn. 2014. When Middle-Class Parents Choose Urban Schools: Class, Race, and the Challenge of Equity in Public Education. Chicago: University of Chicago Press.

Posey-Maddox, Linn, and Anna Haley-Lock. 2016. “One Size Does Not Fit All: Understanding Parent Engagement in the Contexts of Work, Family, and Public Schooling." Urban Education (https://doi.org/10.1177/0042085916660348).

Posey-Maddox, Linn, Shelley McDonough Kimelberg, and Maia Cucchiara. 2016. "Seeking a 'Critical Mass': Middle-Class Parents' Collective Engagement in City Public Schooling.” British Journal of Sociology of Education 37(7):905-27.

Rafalow, Matthew H. 2018. "Disciplining Play: Digital Youth Culture as Capital at School.” American Journal of Sociology 123(5):1416-52.

Ray, Victor. 2019. “A Theory of Racialized Organizations.” American Sociological Review 84(1):26-53.

Reardon, Sean F., and Ann Owens. 2014. "60 Years after Brown: Trends and Consequences of School Segregation.” Annual Review of Sociology 40(1):199-218.

Rhodes, Anna, and Stefanie DeLuca. 2014. "Residential Mobility and School Choice among Poor Families." Pp. 136-66 in Choosing Homes, Choosing Schools, edited by A. Lareau and K. Goyette. New York: Russell Sage Foundation.

Robinson, Keith, and Angel L. Harris. 2014. The Broken Compass: Parental Involvement with Children's Education. Cambridge, MA: Harvard University Press.

Roksa, Josipa, and Daniel Potter. 2011. "Parenting and Academic Achievement: Intergenerational Transmission of Educational Advantage." Sociology of Education 84(4):299-321.

Rønning, Marte. 2011. “Who Benefits from Homework Assignments?” Economics of Education Review 30(1):55-64.

Ryan, Patty. 2016. “Hospital Ratings Controversy Rages On.” Physician Leadership Journal 3(6):12. 
Scarrow, Susan E. 2007. "Political Finance in Comparative Perspective." Annual Review of Political Science 10(1):193-210.

Schieman, Scott, Leah Ruppanner, and Melissa A. Milkie. 2018. "Who Helps with Homework? Parenting Inequality and Relationship Quality among Employed Mothers and Fathers." Journal of Family and Economic Issues 39(1):49-65.

Seamster, Louise, and Raphaël Charron-Chénier. 2017. "Predatory Inclusion and Education Debt: Rethinking the Racial Wealth Gap." Social Currents 4(3):199-207.

Shedd, Carla. 2015. Unequal City: Race, Schools, and Perceptions of Injustice. New York: Russell Sage Foundation.

Sikkink, David, and Michael O. Emerson. 2008. "School Choice and Racial Segregation in US Schools: The Role of Parents' Education.” Ethnic and Racial Studies 31(2):267-93.

Silver, Ira. 2007. "Disentangling Class from Philanthropy: The Double-Edged Sword of Alternative Giving." Critical Sociology 33(3):537-49.

Streib, Jessi. 2015. The Power of the Past: Understanding Cross-Class Marriages. Oxford, UK: Oxford University Press.

Sui-Chu, Esther Ho, and J. Douglas Willms. 1996. "Effects of Parental Involvement on Eighth-Grade Achievement." Sociology of Education 69(2):126-41.

Tate, Allison Slater. 2018. "Some Elementary Schools Are Getting Rid of Homework—and Experts Say It's OK.” TODAY.Com. Retrieved September 15, 2019 (https://www.today.com/parents/teachersparents-just-say-no-elementary-school-homework-t136573).

Tilly, Charles. 1999. Durable Inequality. Berkeley: University of California Press.

Tomaskovic-Devey, Donald, and Dustin Avent-Holt. 2016. "Observing Organizational Inequality Regimes.” Pp. 187-212 in A Gedenkschrift to Randy Hodson: Working with Dignity, Vol. 28, Research in the Sociology of Work. Bingley, UK: Emerald Group Publishing Limited.

(https://doi.org/10.1108/S0277-283320160000028013). 
Tompkins-Stange, Megan E. 2016. Policy Patrons: Philanthropy, Education Reform, and the Politics of Influence. Cambridge, MA: Harvard Education Press.

Vatterott, Cathy. 2011. "Making Homework Central to Learning." Educational Leadership 69(3):60-64.

Villalobos, Ana. 2014. Motherload: Making It All Better in Insecure Times. Berkeley: University of California Press.

Weick, Karl E. 1976. "Educational Organizations as Loosely Coupled Systems.” Administrative Science Quarterly 21(1):1-19.

Weininger, Elliot B. 2014. "School Choice in an Urban Setting." Pp. 268-94 in Choosing Homes, Choosing Schools, edited by A. Lareau and K. Goyette. New York: Russell Sage Foundation.

Wenglinsky, Harold. 1997. "How Money Matters: The Effect of School District Spending on Academic Achievement." Sociology of Education 70(3):221-37.

Wright, Eric R., and Brea L. Perry. 2010. "Medical Sociology and Health Services Research: Past Accomplishments and Future Policy Challenges." Journal of Health and Social Behavior 51(1_suppl):S107-19.

Xu, Jianzhong. 2011. "Homework Completion at the Secondary School Level: A Multilevel Analysis." Journal of Educational Research 104(3):171-82.

Zimmer, Ron, and John T. Jones. 2005. "Unintended Consequence of Centralized Public School Funding in Michigan Education.” Southern Economic Journal 71(3):534-44.

Zukin, Sharon, Scarlett Lindeman, and Laurie Hurson. 2017. "The Omnivore's Neighborhood? Online Restaurant Reviews, Race, and Gentrification.” Journal of Consumer Culture 17(3):459-79.

Jessica McCrory Calarco is an associate professor of sociology at Indiana University and the author of Negotiating Opportunities: How the Middle Class Secures Advantages in Schools (Oxford 2018). 
Table 1. Parent and Student Participants by Participation, Socioeconomic Status, Race, and Ethnicity

\begin{tabular}{|c|c|c|c|c|}
\hline & $\begin{array}{c}\text { Surveys and } \\
\text { Observations }^{\mathrm{a}}\end{array}$ & $\begin{array}{l}\text { School } \\
\text { Records }\end{array}$ & $\begin{array}{c}\text { Student } \\
\text { Interviews }\end{array}$ & $\begin{array}{c}\text { Parent } \\
\text { Interviews }\end{array}$ \\
\hline Higher-SES, White, Non-Hispanic/Latinx & 46 & 38 & 12 & 15 \\
\hline Lower-SES, White, Non-Hispanic/Latinx & 17 & 14 & 9 & 9 \\
\hline Higher-SES, Asian American & 7 & 3 & & \\
\hline Higher-SES, Latinx (any race) & 1 & & & \\
\hline Lower-SES, Latinx (any race) & 7 & 4 & & \\
\hline Higher-SES, Mixed-Race (Black/White) & 1 & 1 & & \\
\hline Lower-SES, Mixed-Race (Black/White) & 1 & 1 & & \\
\hline Total & 80 & 61 & 21 & 24 \\
\hline
\end{tabular}

aThe total observation sample included more than 100 students. This table includes students whose parents also completed a background survey, which I used to determine socioeconomic status, race, and ethnicity. 


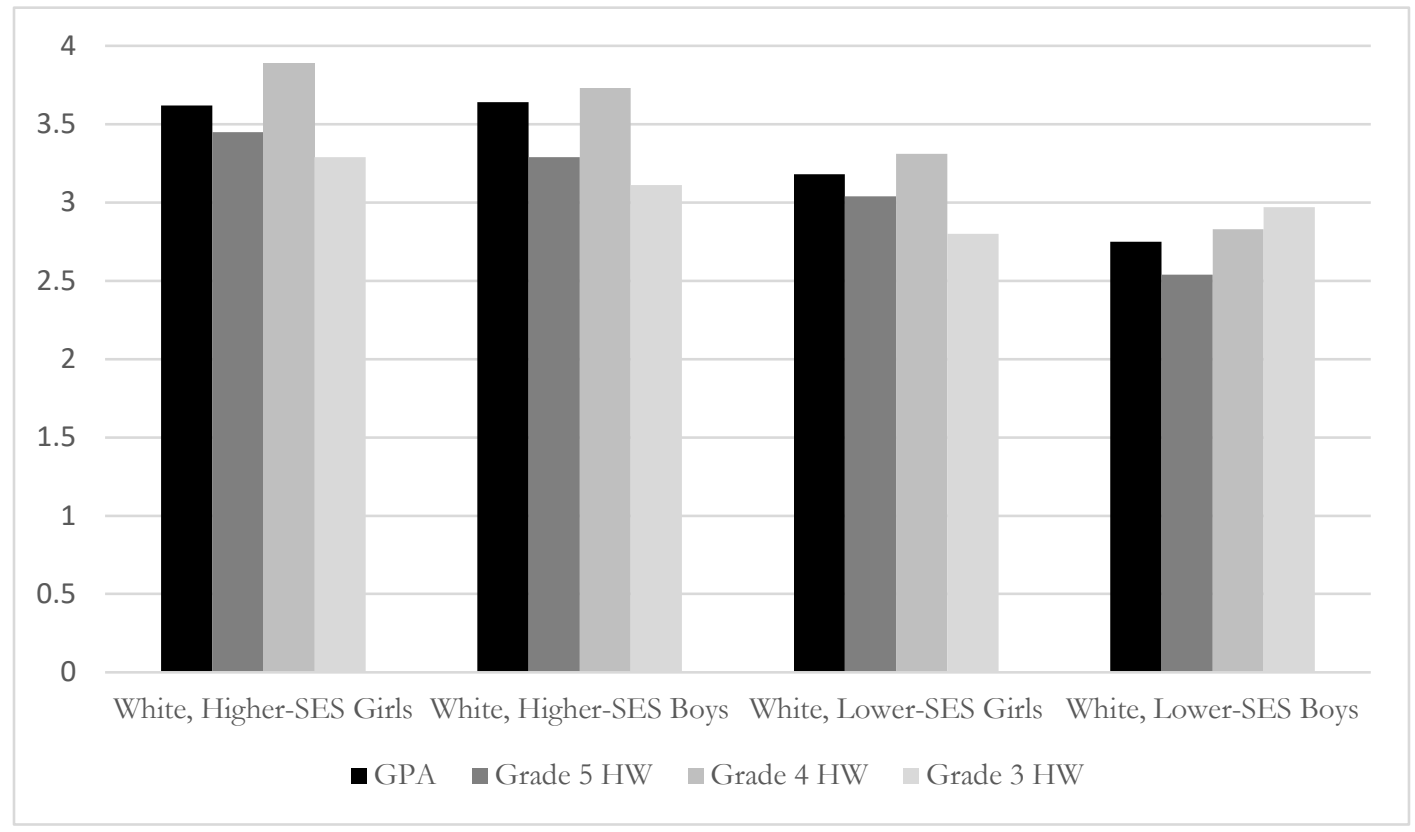

Figure 1. Teacher Ratings of Homework Efforta and GPAb; Means by Grade Level, SES, and Gender. See Appendix A for more information regarding the calculation of mean homework effort ratings and mean GPA. 